\title{
A REPRESENTAÇÃO DA MEMÓRIA NA OBRA POR PARTE DE PAI DE BARTOLOMEU CAMPOS QUEIRÓS
}

\section{The memory representation in the work Por parte de pai by Bartolomeu Campos}

\section{Queirós}

\author{
Márcia Angélica Pontes da Silva ${ }^{1}$ \\ Profa. Dra. Silvana Maria Pantoja dos Santos ${ }^{2}$
}

RESUMO: Objetiva-se com este artigo analisar a representação da memória na obra Por parte de pai, de Bartolomeu Campos Queirós. Para tanto, propõe-se a identificação de elementos constitutivos da memória individual e coletiva. As memórias do narrador trazem as miudezas do cotidiano, contextos de vida de um tempo na companhia dos avós. A obra apresenta uma linguagem poética que arremata as emoções, ultrapassa tempo e espaço, toca as memórias, remexe e deixa transbordar sensações. Sendo a memória a capacidade de conservação das lembranças, procura-se investigar os seus desdobramentos para a formação do sujeito que se enuncia. Para tal abordagem, pautou-se no pensamento de Halbwachs (2006), Le Goff(1996), Bosi (1994), dentre outros, capazes de mostrar argumentos que confirmam que a obra de cunho memorialístico é, sem dúvida, um importante objeto de ressignificação do vivido.

Palavras-chave: Memória. Representação. Bartolomeu Campos Queirós.

ABSTRACT: This article has the purpose to analyze the memory representation in the book Por parte de pai, written by Bartolomeu Campos de Queirós. Therefore, it proposes the identification of constitutive elements of the individual and collective memories. The memories of narrator have brought the daily details, life contexts of the time when he was in the company of the grandparents. The book presents a poetic language which has linked the emotions, overtake time and space, touch the memories, stir and let to overflow sensations. Since the memory, the capacity of remembrance, it was sought to investigate its unfolding for the subject formation who enunciate itself. For this approach, it was based on the Halbwachs (2006) thought, Le Goff (1996), Bosi (1994), among others, they are able to show arguments which confirm that the work has a memorialistic characteristic is, without doubt, an importante object of lived ressignification.

Key words: Memory. Representation. Bartolomeu Campos Queirós.

\footnotetext{
${ }^{1}$ Mestranda em Literatura pela Universidade Estadual do Piauí - UESPI. Especialista em Literatura, Estudos Culturais e Outros Gêneros da Universidade Estadual do Piauí - UESPI.

${ }_{2}$ Profa. Dra. em Teoria Literária. Profa. da Disciplina Literatura e Memória do Curso de PósGraduação em Literatura, Estudos Culturais e outros gêneros, da Universidade Estadual do Piauí UESPI.
} 


\title{
1. INTRODUÇÃO
}

\begin{abstract}
Memória não tem filtro e armazena tudo. Memória a gente não rasga, não joga no lixo, não lava com sabão. Memória é sentinela, e nos vigia sempre. A memória não vê mas não tira o olho. Vai somando vida afora. Tudo que a gente olha, ouve, toca, come, cheira, a memória não esquece. $E$, de repente, transborda mais rápido que enchente. Coisas que a gente só imaginou, a memória guarda. $E$ fatos que a gente nem sabia que sabia rompem sem mais nem menos no pensamento (...). E chegar ao mundo com 57 anos é ter, desde cedo, um grande peso de memória.
\end{abstract}

(Bartolomeu Campos Queirós).

Tratando-se de representações da memória, cumpre reportar-nos ao pendamento de Le Goff (1996). Para esse sociólogo, a memória é a propriedade de conservar informações; é o conjunto de funções psíquicas, graças às quais o homem pode atualizar impressões ou informações passadas, ou que ele representa como passadas. Destarte, temos que: "o ato mnemônico fundamental é o comportamento narrativo", caracterizado, sobretudo, pela sua função social, pois, "é comunicação a outrem de uma informação, na ausência do acontecimento ou do objeto que constitui o seu motivo" (LE GOFF, 1996, p. 224-225).

Nesse sentido, a literatura de Bartolomeu Campos Queirós encontra seu espaço como mantenedor da tradição familiar, tendo suas bases na memória. Assim, objetiva-se com esse trabalho analisar a representação da memória na obra Por parte de pai, de Bartolomeu Campos Queiros.

O escritor e poeta Bartolomeu Campos de Queirós viveu sua infância em Papagaio, uma cidade localizada no interior de Minas Gerais, tendo escrito vários livros e peças teatrais para crianças, envolvendo tanto a arte como a educação. $O$ escritor começou a publicar suas obras de Literatura Infantil nos anos 70, inaugurando sua carreira com o livro O peixe e o pássaro (1974), mas não para só neste, posteriormente vieram outras obras, tais como: Pedro (1981), Onde tem bruxa tem fada... (1979), Fada afiada (1997), Ciganos (1982), Flora (2001), Indez (1986), Correspondência (1986), Por parte de pai (1995), Minerações (1991), Apontamentos (1989), As patas da vaca (1989), Diário de classe (1992), Ler, escrever e fazer conta de cabeça (1996), dentre outros. 
O autor foi contemplado com os mais importantes prêmios no Brasil pelo seu dedicado trabalho com a literatura: Selo de Ouro da Fundação Nacional do livro Infantil e Juvenil, Prêmio Prefeitura de Belo Horizonte, Prêmio Bienal Internacional de São Paulo, O melhor para jovem, Prêmio Jabuti da câmera Brasileira do Livro, Grande Prêmio da APCA - Associação Paulista dos Críticos de Arte, Prêmio Orígenes Lessa - Fundação Nacional do Livro Infantil e Juvenil, Diploma de Honra do IBBY, Quatríeme Octogonal - França, Rosa Blanca de Cuba, Bienal de Belo Horizonte.

Lima e Pereira destacam o valor da obra ao fazerem a seguinte afirmação:

Acredita-se que o reconhecimento mais valioso para este escritor é o prazer que os leitores, independente da faixa etária, sentem quando provam suas palavras poéticas, instrumentos que despertam em muitos leitores a sua parcela mito-poético, na acepção de Glória Kirinus (1988). Logo, retornar à infância, através das obras de Bartolomeu, é abrir a porta para deixar viver a nossa criança mágica. Esse é o sentimento que nos habita ao lermos suas memórias poéticas (LIMA; PEREIRA, 2008, p.118).

Retomando essa concepção, Coelho (2006) acrescenta que Bartolomeu ocupa um lugar significativo na atual produção literária brasileira, sobretudo atraindo um público infantil e juvenil. No entanto, sua produção não é voltada especificamente para o público infantil e juvenil, tendo em vista que suas narrativas possibilitam pensar sobre a condição humana nas mais diversas instâncias.

Como atesta Mendes (2000), "Bartolomeu Campos Queirós (Por parte de Pal), Carlos Heitor Cony (Quase memória), Ignácio de Loyola Brandão (Veia bailarina) e João Gliberto Noll ( $O$ céu aberto) como ícones de uma encenação permanente do sujeito no resgate da memória.". Além disso, afirma que é possível observar uma questão crucial apresentadas no emaranhado de vozes que há um eu que se encena permanentemente. "Quem é essa voz que se diz "eu"? Quantas vozes falam através dela? Que histórias transcritas nas paredes da (memória) casa, Bartolomeu Campos Queirós, artesão artífice da palavra lavrada, nos ensina a ouvir? Que segredos a desvendar?

A obra Por parte de pai, publicado em 1995, enfatiza a paixão do avô pela escrita, o hábito quase religioso de escrever nas paredes da casa, todo e qualquer acontecimento da cidade, além do amor silencioso entre o neto e o avô, são matérias principais dessa obra. Os gestos lentos de S. Queirós, bem como sua 
constante atitude contemplativa perante a janela de casa, a olhar para a rua e seus transeuntes, as histórias de assombração da avó e o crescimento de um medo, aparentemente inexplicável, são também componentes dessa narrativa memorialística.

\section{TESTEMUNHO DE INFÂNCIA: TRAÇOS MEMORIALÍSTICOS EM POR PARTE DE PAI DE BARTOLOMEU CAMPOS QUEIRÓS}

A obra Por parte de pai apresenta um enredo marcado por tons de comicidade, de nostalgia, por meio de um transbordar de fortes emoções. Nesse sentido, o enredo configura-se como uma narrativa psicológica, já que traz as memórias de um narrador adulto, para o plano central da narrativa.

A própria capa do livro, em um amarelo esmaedico, guarda também páginas amareladas de um passado que não escoa: com fotografias emolduradas, a capa realça a foto dos avós, reforçando a revivência. O enredo é contado por um narrador protagonista que rememora cenas de sua infância na casa dos avós, na rua da paciência:

\footnotetext{
Debruçado na janela meu avô espreitava a rua da paciência, inclinada e estreita. Nascia lá em cima, entre casas miúdas e se espichava preguiçosa morro abaixo. Morria depois da curva, num largo com sapataria, armazém, armarinho, farmácia, igreja, tudo perto da escola Maria Tangará, no alto de São Francisco. (QUEIRÓS, 1995, p.70)
}

Nesse sentido, o excerto concentra a temática central da obra, que remete ao tempo e o repensar dos seus efeitos. É Interessante destacar na obra a representação da família, já que o narrador torna-se o centro dessa instituição que se completa não pela presença da mãe, já que esta faleceu, nem do pai, que já constitui outra família, mas sim pela presença dos avós, figuras decisivas na vida do personagem, já que são estes que lhe dão sustentáculo. Por meio da memória individual a obra vai demonstrar o tempo de descobertas: o menino explana por meio da narrativa as angústias em relação aos saberes e dogmas que the são apresentados.

Em Por Parte de Pai, o narrador personagem retoma as lembranças de uma infância plena de movimento. As imagens remontam a um passado distante, 
exalando cheiro de saudade, melancolia. Toda a narrativa gira em torno da casa do avô do narrador, foi lá que o menino adquiriu muitos de seus valores. A casa é o espaço que propicia a rememoração de vivências do infanto-narrador, por esse motivo é a descrição da rua em que ela se localiza que abre e fecha o livro. A residência, com suas paredes estampadas e os cômodos, funcionam como páginas de um grande livro. $\mathrm{O}$ avô escreve e a avó enreda o neto com histórias de assombração. $O$ espaço da casa é geralmente tomado como palco de narrativas que contam a história de famílias, assim, em Por parte de pai, a casa não é mero palco para o desenrolar das ações, mas sobretudo de sentimentos que tecem a trama.

A partir da casa, o narrador ressignifica a infância e, nesta, a relação intensa vivida com o avô e a avó paternos. O narrador estabelece, pelo movimento da memória, o desenho da sua genealogia por parte de pai. Para reconstruir a si mesmo, por intermédio da memória, a casa passa a ser o espaço agregador de aconchego e proteção. Observa-se então, que a memória não é constituída apenas por sua relação com o tempo, mas também por sua relação com o espaço. Halbwachs (2006, p. 157) ensina que "as imagens habituais do mundo exterior são partes inseparáveis de nosso eu", sendo assim, os espaços habitados e os objetos que nele se inserem constituem a subjetividade dos sujeitos. Por ser o local gerador da memória e, portanto, de todo o enredo, a casa recebe descrições detalhadas: as escadas, o quarto, o quintal, a cozinha, as janelas, dentre outros espaços que compõem um todo significativo.

Em Por parte de pai, também é evidente o testemunho de si no ato de rememorar. O narrador recorta passagens vividas na casa em que o medo é a mola propulsora. A própria casa provoca medo no menino/narrador, medo de fantasmas, durante a noite, marcando o fantástico, tão característico da memória dos casos, lendas e contos mineiros:

Pelas frestas da janela soprava um vento resmungando, cochichando, esfriando meus pensamentos, anunciando fantasmas. As roupas dependuradas em cabides na parede se transfiguravam em monstros e sombras. Deitado, enrolado, parado, imóvel, eu lia recado em cada mancha, em cada dobra, em cada sinal. O barulho do colchão de palha me arranhava. O escuro apertava minha garganta, roubava meu ar. O fio da luz terminava amarrado na cabeceira do catre. O medo, assim maior do que o quarto, me levava a apertar a pera de galalite e acender a luz enfeitada com papel crepom. O claro me devolvia as coisas em seus tamanhos 
verdadeiros. O nariz do monstro era o cabo do guarda chuva, o rabo do demônio o cinto de meu avô, o gigante, a capa "Ideal" cinza para os dias de chuva e frio. Então procurava distrair meu pavor decifrando os escritos na parede, no canto da cama, tão perto de mim." (QUEIRÓS, 1995, p. 17-18).

O fragmento acima expressa que os espaços tão cotidianos para o menino Ihe despertam horror em decorrência da escuridão da noite. Ele lê cada detalhe das coisas.

Esta obra de Bartolomeu fortalece um eixo para a concepção evocativa da memória. O amor silencioso entre o neto e o avô refletem as lembranças do menino, resgatadas pela infância, os momentos felizes de interação com os irmãos, o convívio com a mãe e suas brincadeiras, aconchego e da segurança proporcionados pelo pai.

A partir disso, vai tecendo os fatos mais marcantes, interessantes e dolorosos dessa fase, como quando o avô comprou a casa com o dinheiro que ganhou na loteria, devido a um sonho que a avó teve. Relata que as paredes eram enfeitadas com a letra bonita do avô, que anotava tudo o que acontecia na cidade, como também a convivência entre os princípios religiosos cristãos e as superstições da avó. As vizinhas Fé, Esperança e Caridade, o amor por Jeremias, o galo de estimação que acaba sendo morto, até a doença da avó e as tristezas trazidas com ela, o seu crescimento e amadurecimento auxiliado pelas conversas do avô sobre a vida. Assim, num ritmo de memória, lento e calmo, registra acontecimentos, fatos e impressões.

O narrador utiliza-se do discurso indireto para narrar às ações, "contei para meu avô e ele me pediu segredo. "Quem fala muito, dá bom-dia a cavalo", afirmou. Fiquei na maior vontade de encontrar um cavalo para cumprimentar" (QUEIRÓS, 1995, 32), ou "só podia ter sido uma vertigem, explicava meu avô ao doutor Heleno" (QUEIRÓS, 1995, p. 56). Desse modo, vale ressaltar que o texto menos de se estruturar em uma relação lógico-causal, é marcada por um processo de avanços e recuos de lembranças. O "bom-dia a cavalo" reforça que a narrativa cria ou realça muitos provérbios que permeiam o imaginário coletivo, como "Em casa sem forro, nem cheiro fica escondido” (p. 36), “.... banana de manhã é ouro, de dia é prata e de noite mata." (p. 49), "Não existe sete vidas nem sete fôlegos. Tudo acaba em sete 
palmos", "Deus é corcunda: dá a vida e toma" (p. 59), "Para quem sabe ler, um pingo nunca foi letra" (p. 63).

Com a quebra de temporalidade, a duração das ações é pouco definida, no entanto, compreende-se o tempo histórico em que se passaram os fatos por trechos como, "a Alice nos visitou às 14 horas do dia 3 de Outubro de 1949 e trouxe recomendações da irmã Julia e do filho Zé Maria lá de Brumado" (QUEIRÓS, 1995, p.11) e ainda "Fé, Esperança e Caridade assistiam "O direito de nascer", como única diversão"(QUEIRÓS, 1995, 23), nesta, observa-se que se trata da década de 1950, período em que essa novela era transmitida pelo rádio.

Ademais, o narrador personagem apresenta diversos, dos muitos costumes do século XIX, de algumas cidades do interior mineiro: a avó fazendo bico de crochê em pano de prato, trocando receitas, devolvendo copo de açúcar, rezando novena, debulhando o rosário entre os dedos, ou ajudando doentes; o avô que jogava no bicho, adivinhando e apostando pelos sonhos dos outros, urinava no penico; as solteironas exalando o cheiro do caximir-buquê por onde passavam; as locomotivas passando e apitando; o hábito de se cozinhar usando gordura de coco Carioca; o banho em banheira com água de serpentina; e o hábito de se bater em criança com cinta de couro.

Por parte de pai reúne diversos outros traços memorialísticos como: a contação de casos, o valor da escrita e sua relação com a escola, a identidade, tradição e folclore, sobrenatural e maravilhoso. A primeira parte da obra é repleta de relatos memorialísticos, em que $o$ infanto-narrador delineia sua familiaridade com a escrita e a contação de casos, desde muito cedo. A escrita do avô incitava a capacidade de criação do menino e instigava o seu medo:

Enquanto ele escrevia, eu inventava histórias sobre cada pedaço da parede. A casa do meu avô foi meu primeiro livro. Até história de assombração, tinha. Era de Maria Turum, preta que foi escrava, não sei se veio de navio negreiro, e ajudou a criar os filhos. Antes de morta, já tinha bicho no corpo de tanto ficar na cama, fraca, inválida, velha. Eu olhava para ela e pensava que viver era encolher, diminuir, subtrair. Cada dia ela ficava menor. Sua alma costumava passear no terreiro em noites de sextas-feiras, assustando cachorros, gatos, galinhas. Andava também pelo corredor da casa, rangendo as tábuas do assoalho, implorando missa (QUEIRÓS, 1995, p. 12-13). 
Bartolomeu Campos de Queirós recupera, em larga medida, a dimensão da memória na composição de seus livros. A análise é constante e profunda, o que se pode perceber ainda em:

As paredes eram o caderno do meu avô. Cada quarto, cada sala, cada cômodo, uma página [...] para cada notícia, escolhia um canto. Conversa mais indecente ele escrevia bem no alto. Era preciso ser grande para ler, ou aproveitar quando não tinha ninguém em casa. Caso de visitas ele anotava o dia, a hora, o assunto ou a falta de assunto. Nada ficava no esquecimento, em vaga lembrança [...] enquanto ele escrevia, eu inventava histórias sobre cada pedaço da parede. A casa do meu avô foi o meu primeiro livro. Até história de assombração tinha (QUEIRÓS, 1995, p. 11).

As últimas referências feitas na obra a esse memorial cheio de cumplicidade entre avô e neto são as seguintes: "Meu pai chegou no meio da tarde... Passei os olhos pelas paredes conferindo as páginas e minha memória. Eu sabia cada pedaço, cada margem, cada entrelinha desse livro" (QUEIRÓS, 1995, p. 72).

As lembranças do grupo doméstico persistem matizadas em cada um de seus membros e constituem uma memória ao mesmo tempo diferenciada. Acrescenta Ecléa Bosi (1994, p. 423) que os vínculos podem persistir mesmo quando se desagregou o núcleo onde a história teve origem. As marcas do catolicismo, das rezas e das procissões, por exemplo, estão presentes na narrativa. Há todo um contexto de formação religiosa permeando a vida do menino, com rituais religiosos, período de quaresma, beijos em faixas da igreja, visitas de Nossa Senhora, a imagem que saía de casa em casa:

Havia uma banheira. A água quente vinha da serpentina dobrada dentro do fogão. Era só atiçar o fogo para a água cair fervendo. Eu não gostava de tomar banho em banheira. Vinha uma vontade imensa de chorar, não sei se de dor ou de lembrança. Bobagem minha, pois chorar dentro d’água é bem mais fácil de despistar. Meu avô me ensinou desde muito pequeno a não chorar. Choro não era coisa de homem. Nunca vi uma lágrima em seus olhos (QUEIRÓS, 1995, p. 55).

Segundo Halbwachs (2006) a memória coletiva é pautada na continuidade e deve ser vista sempre no plural (memórias coletivas). Justamente porque a memória de um indivíduo ou de um país estão na base da formulação de uma identidade, que a continuidade é vista como característica marcante. A História, por outro lado, 
encontra-se pautada na síntese dos grandes acontecimentos da história de uma nação, o que para Halbwachs faz das memórias coletivas apenas detalhes.

A desenvoltura do processo mnemônico do narrador volta-se para a constituição da memória indivídual articulada a uma combinação de memórias do grupo ao qual pertence.

Pensando devagar, acordado na madrugada, eu descobria as tantas coisas sabidas, mas não vistas e outras vistas e não sabidas. Por exemplo, Dona Aurora, que não era boreal como na Geografia, me ensinou desde cedo, estar Deus em toda parte. Eu não via. Também não queria ver e padecia com o pecado cometido negando ver 0 Onipresente. O demônio ficava contente e Padre Libério me benzia. O sofrimento me machucava inteiro. Eu encolhia, escondia, pedia perdão e continuava afogado em dúvidas. As três caravelas - Santa Maria, Pinta e Nina eu não via, mas até desenhava. Doía muito ser menino (QUEIRÓS, 1995, p. 22).

Cenas relatadas como a relação carinhosa e acolhedora entre o menino e a primeira professora; o amor silencioso dos pais, traduzido em cuidados; a capacidade que a mãe tinha de criar brincadeiras, exercendo sua criatividade num ambiente simples, colorindo galinhas com água e anilina; a temporada em casa do avô paterno são diversos dos fatos vividos, ainda que fundidos com elementos fantasiados ou sonhados.

O indivíduo participa, então, de dois tipos de memória (individual e coletiva) e isso se dá na medida em que "o funcionamento da memória individual não é possível sem esses instrumentos que são as palavras e as ideias, que o indivíduo não inventou, mas que toma emprestado de seu ambiente" (HALBWACHS, 2006, p. 72). Ao mesmo tempo, "na base de qualquer lembrança haveria o chamamento a um estado de consciência puramente individual" (HALBWACHS, 2006, p. 42) que permite a reconstituição do passado de forma que haja particularidades nas lembranças de cada um. Isso significa que, mesmo fazendo parte de um grupo, o indivíduo não se descaracteriza e consegue distinguir o seu próprio passado.

As palavras da personagem são reveladoras da situação, dessa maneira, a memória coletiva engloba a memória do grupo e cada componente desse grupo com ela se identifica. O grupo é portador da memória e esta é consensualizada mediante as relações que se estabelecem dentro do próprio grupo. É no contexto dessas relações que se constroem as lembranças que estão impregnadas das memórias 
dos que nos cercam, de maneira que, ainda que não estejamos em presença destes, o nosso lembrar e as maneiras como percebemos e vemos o que nos cerca se constituem a partir desse emaranhado de experiências (HALBWACHS, 2006).

Segundo Freud (1986, p. 271), as recordações fragmentárias dos primeiros anos da infância permanecem na memória. O psicanalista mostra também que o tema lembranças de infância está marcado na leitura de memórias de infância, quando ele afirma que ninguém contesta o fato de que as primeiras experiências dos primeiros anos de nossa infância deixam traços inerradicáveis nas profundezas da mente. Vimos que, o que mais se fixa no menino-narrador são as lembranças de como o avô usava as paredes da casa como suporte para a escrita: uma casa escrita. As paredes estampadas de registros, de histórias ao mesmo tempo dispersas e integradas, uma narrativa em labirinto.

Frente ao exposto Freud (1986) acrescenta que a rememoração se daria com a forma de acontecimentos não mnêmicos. É a repetição em que o ato repetido faz as vezes de lembrança. Freud se refere a um tipo de memória encobridora, uma montagem ou uma colagem de lembranças de épocas diferentes. A demarcação entre lembrança e fantasia dá lugar a dúvidas. Por isso a memória pode atuar a própria memória, ao substituir uma lembrança por uma montagem. Seria resistência a lembrar através da criação de disfarces, de derivados.

Enquanto o avô escrevia, o menino inventava histórias sobre cada pedaço da parede. Imagens e palavras estão entre os mais importantes componentes da memória narrativa, operando juntas, interligando o semântico e o sensorial na utilização quotidiana, embora seja útil separá-las, de certa forma, considerando, nas narrativas, a memória sensorial em primeiro lugar, e em segundo a memória semântica. Além de representar a rememoração possibilita interligar, esclarecer e fornecer explicações para interpretar de si mesmo, tanto quanto para prevenir o que esteja por vir.

Ecléa Bosi (1994, p. 415) mostra que o conjunto de lembranças nos deixa a divisão do tempo que nelas se opera e que a infância é larga, quase sem margens, como um chão que cede a nossos pés e nos dá a sensação de que nossos passos afundam, afirmativa evidenciada no seguinte trecho: 
Se ninguém queria ouvir suas histórias, minha avó se punha a cantar... Meu avô, sem se dar conta vinha se assentar junto de nós e escutava, com admiração, minha avó nos encantar com rainhas deusas, mancebos, heróis cheios de brilhos e vitórias. Com olhar embaçado, ele parecia saber de outras histórias, mas não contava por cuidado (QUEIRÓS, 1995, p. 38-39).

É notável que lembranças de vivências individuais e coletivas fortalecem a percepção do estabelecimento da forte marca memorialística, por meio da sua identificação e do seu encontro com o grupo familiar a que pertence. Beatriz Sarlo diz que "o testemunho é inseparável da autodesignação do sujeito que testemunha porque ele esteve ali onde os fatos aconteceram" (SARLO, 2007, p. 50).

Elias José (2012, p. 11) "expõe que o ato de rememorar é o modo que o homem encontra para fazer uma reflexão sobre a sua trajetória de vida em um tempo e em um espaço culturais". Ele ainda acrescenta que "a memória possibilita ao homem a noção de identidade e o reconhecimento como parte de um grupo, de uma sociedade que está sempre em mudança".

\section{CONSIDERAÇÕES FINAIS}

Constatou-se que na obra Por parte de Pai de Bartolomeu Campos Queirós, há uma constante fusão entre literatura e memória que permite ao protagonista reelaborar suas vivências de apanhado memorialístico. O infanto-narrador, por meio da imersão no passado, promove a reflexão sobre suas memórias relacionando-as a espaços de vivências.

Identifica-se no percurso da memória o conjunto de conhecimentos socialmente adquiridos ou produzidos, e historicamente reunidos e associados, expressando a universalidade e objetividade que permitem sua transmissão, com linguagem própria e reveladora de pulsões.

$O$ afeto se faz presente na narrativa até mesmo quando o narrador personagem segreda a dor da existência. No mundo da imaginação, assim como na realidade, é possível enganar a tristeza com suspiros e gemidos. Dessa forma, este estudo mostrou-se pertinente ao que se propôs analisar. A memória se inicia pelo registro de um fato acontecido. O registro é um código fixado. E como marca retida, a memória constitui-se como referência dentro da mente, para desencadear novos 
desdobramentos como nas percepções, nas apercepções, nas identificações e reconhecimentos, nas codificações, na atenção, nas emoções, nas evocações.

Além disso, é sem dúvida mais um trabalho a compor a fortuna crítica do autor, integrando-se aos estudos de obras destinadas ao leitor adulto, revelando mais uma faceta do repertório literário.

\section{REFERÊNCIAS}

BOSI, Ecléia. Memória e sociedade: lembranças de velhos. 2 ed. São Paulo: Companhia das letras, 1994.

BRANDÃO, Vera Maria Antonieta Tordino. Labirintos da memória: quem sou? São Paulo: Paulus, 2008.

COELHO, Nelly Novaes. Literatura infantil: teoria, análise, didática. São Paulo: Moderna, 2000.

FREUD, Sigmund. Lembranças encobridoras. In: Obras psicológicas completas: edição standard brasileira. V. III, 2 ed. Rio de Janeiro: Imago, 1986.

HALBWACHS, Maurice. A memória coletiva. Trad. de Beatriz Sidou. São Paulo: Centauro, 2006.

LIMA, M.M. Soares de; PEREIRA, Jaquelânia A. A infância poética em Bartolomeu Campos de Queirós: uma leitura de Ler, escrever e fazer conta de cabeça. In: PINHEIRO, H. PEREIRA, J. A e NETO, M.A. (orgs). Literatura e formação de leitores. Campina Grande: Bagagem, 2008.

JOSÉ, Elias. Memória, cultura e literatura: o prazer de ler e recriar o mundo - São Paulo: Paulus, 2012.

LE GOFF, Jacques. História e memória. 4 ed. Campinas, Ed. da UNICAMP, 1996

QUEIRÓS, Bartolomeu Campos. Por parte de pai. São Paulo: Editora Moderna, 1995.

SANTOS, Silvana Maria Pantoja dos. Literatura e memória entre os labirintos da cidade: representações na poética de Ferreira Gullar e H. Dobal. - São Luís: Editora UEMA, 2015.

SARLO, Beatriz. Retórica testemunhal. In: Tempo passado: cultura da memória e guinada subjetiva. Trad. Rosa Freire d' Aguiar. São Paulo: Companhia das letras, Belo Horizonte, UFMG, 2007. 